\title{
WHY IS THERE CODE SWITCHING IN EFL CLASSROOM? : A CASE STUDY IN A VOCATIONAL SCHOOL IN CIMAHI WEST-JAVA
}

\author{
Diana Nur Fathimah \\ Faculty of Postgraduate Studies, Universitas Pendidikan Indonesia \\ E-mail: diananurfathimah@gmail.com
}

\begin{abstract}
Code switching is a common phenomenon that results from the bilingual quality of a language speaker. In the educational context, code switching is frequently found in an EFL classroom of which the teacher is a non-native speaker. It is considered as one of the strategies to facilitate students to learn English more effectively. However, a number of research studies investigating EFL classroom discourse found various reasons of the use of code switching, ranging from the familiarity of the context to the teacher's language proficiency. The present research gears toward investigating code-switching practiced by an EFL teacher in Indonesia and the rationale behind that practice. Taking case study method, this qualitative study employs observation and semi-structured interview to gather the data. An English teacher in one vocational school in Indonesia was chosen to be the participant of the research. The research shows that, as a bilingual, the teacher practiced code-switching both in educational context and non-educational context, inter-sententially and intra-sententially. In the classroom context, inter-sentential code switching was practiced deliberately to serve as exposures for students. Meanwhile, intra-sentential code switching was oftentime not a deliberate action, but rather a force of habit of the English teacher as a bilingual.
\end{abstract}

Keywords: Bilingualism, code-switching, EFL classroom

\begin{abstract}
Abstrak
Alih kode merupakan fenomena umum yang dihasilkan dari kualitas bilingual dari penutur bahasa. Dalam konteks pendidikan, alih kode sering ditemukan di dalam kelas EFL dimana guru merupakan pembicara non-pribumi. Hal ini dianggap sebagai salah satu strategi untuk memfasilitasi siswa untuk belajar bahasa Inggris dengan lebih efektif. Namun, sejumlah penelitian yang menyelidiki EFL wacana kelas menemukan berbagai alasan dari penggunaan alih kode, mulai dari keakraban konteks untuk kemahiran berbahasa guru. Penelitian ini bertujuan mengkaji alih kode yang dilakukan oleh seorang guru EFL di Indonesia dan alasan di balik praktek itu. Metode yang digunakan yaitu studi kasus, studi kualitatif dengan menggunakan observasi dan wawancara semi-terstruktur untuk memperoleh data. Seorang guru bahasa Inggris di salah satu sekolah kejuruan di Indonesia dipilih menjadi responden penelitian. Hasil penelitian menunjukkan bahwa, sebagai bilingual, guru berlatih alih kode baik dalam konteks pendidikan dan konteks non-pendidikan, antar-kalimat dan intra-kalimat. Dalam konteks kelas, alih kode antar-kalimat sengaja dipraktekkan untuk pengenalan awal bagi siswa. Sementara itu, kode intra-sentential sering kali dilakukan tidak disengaja, melainkan kebiasaan guru bahasa Inggris sebagai bilingual.
\end{abstract} Kata kunci: Bilingualism, alih kode, EFL kelas 


\section{INTRODUCTION}

As English is considered an important linguistic capital (Saito, 2012), people around the world tend to learn English as a second or foreign language (McKay, 2003). Hence, many people who have already mastered their first language are now becoming multilingual speakers due to the mastery of English as their second or foreign language. The mastery of more than one language encourages people to switch code in various contexts (Holmes, 2001; Gass and Selinker, 2008). Non-native English teachers are among people who have tendency to switch code since they are required to master the language they have to teach.

The use of more than one language or code-switching in a conversation is a common phenomenon among bilingual and multilingual speakers (Bot, Lowie, and Verspoor, 2005; Barnes, 2006; Gass and Selinker, 2008; Ewert, 2010). The reasons behind the practice of code switching are complex and varied (Ewert, 2010). One of the reasons is related to the cognitive process happening in brain (Bot, Lowie, and Verspoor, 2005; Barnes, 2006; Gass and Selinker, 2008; Sharwood-Smith and Truscott, 2008). To some extent, codeswitching is seen as a negative transfer in the process of learning and acquiring the second language (Sharwood-Smith \& Truscoot, 2008). On the other hand, codeswitching is seen in a more positive manner portraying the ability of multilingual speakers to speak in more than one language. According to Green (1986 cited in Bot, Lowie, and Verspoor, 2005) there are three states in which language can be at a certain moment: selected, active, and dormant. The language or code used during a conversation is the selected language; languages playing a role in the background are active languages, and languages which do not play a role during the conversation are dormant languages. Unlike the dormant language, the active language has a tendency to substitute the selected language when speakers cannot find appropriate words in the selected language (Bot, Lowie, and Verspoor, 2005). The emerging of active languages in a conversation then encourage speakers to switch codes.

Moreover, multilingual speakers tend to search words not limited to one language only. The process of selecting words from any language mastered is called non-selective access. Studies show that multilingual speakers tend to practice nonselective access rather than selective access (Bot, Lowie, and Verspoor, 2005). The process of selecting language 'nonselectively' is on account of the single lexical repository concept (Bot, Lowie, and Verspoor, 2005). The languages mastered by multilingual speakers are believed to be grouped in a single subsets and intertwined to each other. However, lexical items in one language can be predominantly used compared to the lexical items in the other language. The frequency is determined by the level of proficiency, frequency of interaction and characteristics of the languages (Barnes, 2006). If the speakers are proficient in the particular language and that language is frequently used in interactions, the tendency of the lexical items to be used will be higher. As multilingual speakers use various languages based on different contexts (Holmes, 2001) the set of lexical items frequently used will not only from one single language. The balance use of various lexical items in particular languages or codes will be found in multilingual speakers, encouraging them to switch code when communicating (Gass and Selinker, 2008).

In multicultural societies, people tend to encounter various settings requiring them to use languages based on speech communities they are talking to (SavilleTroike, 2006). The demand to speak more than one languages in frequently-changed contexts encourages speakers to switch codes. Code-switching reflects a change in the social situation (Barnes, 2006).The 
switch is the process or action of selecting or changing linguistic elements for the sake of effectiveness in communication (Ewert, 2010). Furthermore, Holmes (2001) asserts that the functions of code-switching are showing group and ethnicity membership, talking about particular topic accurately, emphasizing affective functions, and drawing particular association of a code. Nevertheless, code switching does not only triggered by the need to accommodate other people in communication. Ewert (2010) reported that people switch codes not because of accommodating the expectation of other, but because of people internal need.

The reasons behind code switching are considered complex (Holmes, 2001; Ewert, 2010). Nevertheless, many scholars state that speakers switching codes or languages tend to have balance mastery of the languages (Holmes, 2001; Gass and Selinker, 2008; Ewert, 2010). Holmes (2001) further explains that the situation when speaker of a second language use a word from the L1 to cover the lack of knowledge of the appropriate word in the second language is called lexical borrowing. Albeit the difficulty of determining whether speakers switch code due to their lack of proficiency or specific contexts, codeswitching is categorized into intrasentential (a code-switching in a lexical or phrasal levels) and inter-sentential (a code switching in a sentence level)(Rollin-lanziti and Brownlie, 2002 cited in Qing, 2010).

The reasons of code-switching practice based on the individual mind and contexts of language used have been described above. However, the theories discussed above may not be sufficient to reveal the reasons of code-switching in an educational context. Thus, further elaboration on how code-switching is practiced in an educational context needs to be put forward.

The teaching-learning contexts encountered by teacher tend to be designed specifically to meet educational objectives
(Brown, 2000; Harmer, 2007). The practice of code-switching occurred in this context tend to be designed to meet particular educational objectives as well (Qing, 2010). In an EFL English class, the use of codeswitching bridges the need to give students exposure and the accommodation of students with low-proficiency of English (Brown, 2000; Harmer, 2007). This notion is in a similar vein with Peng and Zhang (2009) reporting that the teachers in China tend to practice code-switching since they consider using too much English tends to make their students more anxious and frustrated. Hence, the use of English sometimes is followed by the explanation in L1. On the other hand, Ewert (2010) investigating code-switching practiced by students found that the Polish students learning Russian and English tend to switch code depends on the topic discussed. The students are considered proficient in all the languages. As mentioned previously, switches triggered by lack of proficiency in a speaking test in Ukraine are not categorized as codeswitching but as lexical borrowing (Holmes, 2001).

Although non-native English teachers in EFL tend to switch code generally due to educational reasons. The reasons of code-switching practiced by teacher can be due to non-educational factors such as individual and environmental factors. Teachers in EFL countries tend to use their L1 in their daily communication since English does not have particular position in society (Crystal, 2003; Jenkins, 2009). However, English for English teachers has a distinctive role. Although English, for instance in Indonesia, is considered as a foreign language having no official status (Jenkins, 2009), English teachers will use English more frequent due to the certain demands and roles the teachers have to fulfill. For instance, as English teachers have to complete English teacher education program, the tendency that they 
communicate in English will be high (Cenoz, 2003; Levine, 2003). Hence, nonnative English teachers tend to use their first language and English equally. Relevant with whatGass and Selinker (2008) assert, when the use of two languages are relatively equal, the tendency to switch code in speaking will be high. Thus, since factors encouraging teachers to switch codes are not only educational contexts, the investigation regarding the practice of code-switching conducted by teachers should not be limited to classroom observation.

The reasons for English teachers to switch code vary from educational reasons such as accommodating students with low English proficiency, sociolinguistic reasons such as showing ethnicity or group membership (Holmes, 2001), and reasons related to the notion of second language acquisition such as intensive use of particular language making the language more active than other languages (Bot, Lowie, and Verspoor, 2005; Gass and Selinker, 2008). Plethora of research investigating code-switching practiced by teachers has been conducted. Most of the research reported that code switching mostly is viewed as a sociolinguistic phenomenon (Sharwood-Smith and Truscott, 2008). The reasons of codeswitching practiced by teachers tend to be related to the communicative function of code switching. Nevertheless, research viewing code-switching as a notion related to second language acquisition is still scarce.

The code-switching practiced by English teachers occurs in an educational context. The distinctive characteristic of this context is that the activities are designed to achieve educational objectives. Code switching in educational context is considered as one of the strategies to facilitate students to learn English more effectively (Brown, 2000; Harmer, 2007). In some cases, however, speakers tend to be unaware or unintentional in practicing code switching (Holmes, 2001). A number of research regarding the investigation on code-switching in educational contexts have been put forward. Ewert (2010) reported that code-switching practiced by Polish students learning Russia and English mostly depended on topic of the conversation instead of the situational context. The topics discussed in educational contexts are various, and to some extent are related to particular speech communities. Additionally, Peng and Zhang (2009), who investigated the practice of code-switching in an EFL class in China, found that the teachers practiced code-switching due to the low English proficiency of students. Both investigations demonstrate that the context in which the teachers spoke were the impetus of their code switching.

The issue arises from the fact that the reasons of teacher practicing code switching may not only due to the educational contexts. There are some factors that can encourage teacher to practice code-switching. Some factors can be related to the notion of second language acquisition such as the intensity of the use of the particular language (Bot, Lowie, and Verspoor, 2005). This tendency creates a gap which needs to be investigated. This research is aimed at investigating whether or not an English teacher of a vocational school in Cimahi switches code when teaching and the reasons behind the practices. Hence, this research is geared toward answering the following research questions.

1. Does the teacher switch code when teaching her students?

2. Why does/does not the teacher switch code when teaching her students?

The results of this research are expected to enrich the theories of second language acquisition and code switching. This research reveals whether or not an English teacher of a vocational school in Cimahi 
practices code switching and the reasons behind the particular practice. The results of this research can be used to depict the practice of code switching in educational context as well. Moreover, by reflecting from this research, teachers can contemplate the necessity of switching codes based on the strengths and weaknesses of the code-switching practiced by the teacher in the context of this research.

\section{METHOD}

\section{Research Design}

This research aims at investigating the code-switching practiced by an English teacher of a vocational school in Cimahi. This research belongs to qualitative research employing case study method since it aims at revealing a specific phenomenon experienced by a subject in specific context with the intervention of the researcher in eliciting data (Nunan, 1992; Alwasilah, 1995). The phenomenon investigated in this research is the codeswitching practiced by the teacher related to the context of teaching-learning and background of the teacher. Since this research investigated specific phenomenon in specific context, the findings of the research were not generalized as applicable to other English teachers in different context. However, bigger generalization may be conducted by comparing the findings of this research with the previous research findings.

\section{Participant and Research Site}

The participant in this research was an English teacher of a vocational school in Cimahi. The selection of participant was categorized as purposive sampling since the participant was considered able to give the necessary data (Bailey, 2007; Malik \&Hamied, 2014). The participant was selected since she is considered experienced and knowledgeable in teaching English. She has been learning English for 23 years and teaching English for 12 years. She was also selected as the second best teacher in Cimahi in 2014. Her experience of living abroad was also taken into a consideration. The participant had stayed in Australia for several weeks. Thus, her experience of living in Australia, could be taken as valuable data. In the other words, the participant has mastered English through learning and acquisition.

\section{Data Collection}

This research aims at revealing the codeswitching practiced by the English teacher. The data collected in this research were explanations and oral utterances collected from the interview and a classroom observation. The oral explanations of the teacher were collected from a semistructured interview adapting the questions based on the situations and answers of the participants (Fraenkel, et al, 2012). The interview was tape-recorded and then transcribed. The data related to whether or not the teacher switches code in classroom context were collected from a classroom observation. The utterances uttered by the teacher in the classroom were video recorded and then transcribed. The utterances taken from the semi-structured interview were also analyzed to investigate whether or not the teacher switches code in non-educational context.

\section{Data Analysis}

Data analysis is divided into two main steps. Firstly, to reveal whether or not the teacher switches code, utterances in the classroom activities and interview were transcribed. The utterances in classroom observation were analyzed in order to reveal whether or not the teacher switches code in the educational context, while utterances in the interview were analyzed to reveal whether or not the teacher switches code in non-educational context. The utterances indicating the practice of codeswitching were marked. The categorization of types of code-switching were based on Rollin-lantizi and Brownlie (2002, cited in Qing, 2010) categorizingcode-switching 
into intra-sentential and inter-sentential. Secondly, to unearth the reasons why the teacher practices/does not practice codeswitching, the explanations regarding possible reasons behind the practice were transcribed and analyzed. The possible reasons leading the teachers to switch or not to switch code were marked andanalyzed based on theories proposed by some scholars in the field of second language acquisition (for example Bot, Lowie, and Verspoor, 2005; Barnet, 2006; Gass and Selinker, 2008; and Ewert, 2010) especially in terms of how intensity of using languages influences the practice of code-switching. The theories regarding the practice of code-switching due to sociolinguistic and educational reasons were also utilized to compare and view the findings from different perspectives.

\section{FINDINGS AND DISCUSSION}

\section{Code-Switching in the Educational Context and Non-Educational Context}

This part will elaborate whether or not teacher switches code when teaching her students. The answer of the research questions was based on the analysis of the data collected from the classroom observation and semi-structured interview. According to the data analysis, the teacher practiced code-switching, both in the educational and non-educational contexts.

The classroom activities observed were focused mainly on accommodating students to tell about descriptive texts they had picked in front of the class. The proportion of the teacher to explain materials was relatively small. Hence, only several instances of code-switching were recorded. The total number of instances of code-switching from Indonesian to English recorded were 37 instances, 20 (54.05\%) instances were inter-sentential codeswitching, and the other 17 (45.95\%) instances were intra-sentential codeswitching. This finding is in accordance with Qing (2010) reporting that in the
English teachers in China practiced codeswitching in class mostly in the intersentential form. The examples of codeswitching instances in the form of intersentential code-switching and intrasentential code-switching can be seen in the following excerpts.

The examples of inter-sentential codeswitching:

"Alright who want to come first?

Everyone can you pay your attention to me?"

"The example is Malin Kundang story, right?"

"Once again what is identification? Raise your hand."

"What else after description?"

The examples of intra-sentential code switching.

"Okay sekarang diliat teksnya, kalian pilih the most interesting one".

"Apa WH question itu?"

"Kalau dengan why?"

"Handphonenya disilent dulu."

"Kalau mau menanyakan moral value?"

Besides practicing code-switching in the educational context, the teacher also practiced code-switching in noneducational context. The finding was generated from analysis of the data collected from the semi-structured interview. The analysis shows that the code-switching practiced in the noneducational context, especially in the interview, mostly was in the form of intrasentential code switching.

\section{Code-Switching as a Habit and Form of Accommodating Students' Needs}

The reasons behind the code-switching practiced by the teacher in this context possibly are in line with what Brown (2000) and Harmer (2007) explain regarding giving students the exposure to English. Using and exposing students to English in the class are essential since English classroom 
tend to be the main source of English exposure. On the other hand, EFL teachers have to deal with low English proficiency of students due to the limited context. Fully using English in the class is seen less tangible since students in EFL teachinglearning context tend to have difficulties in understanding full English instruction (Brown, 2000; Harmer, 2007). Switching between languages can be a solution for this problem.

The teacher in this research demonstrates that code-switching the notion proposed by Holmes (2001) regarding using code-switching to talk about particular topic.

\section{CONCLUSION}

The research found that the teacher practices code-switching both in the classroom context and non-classroom context. In the classroom context, the teacher practiced code-switching in the form of inter-sentential code-switching, while in the non-classroom context, especially in the interview, the teacher practiced code-switching in the form of intra-sentential code-switching. The different practices of code-switching in different contexts indicate that codeswitching practiced by the English teacher is not only due to the classroom context where she has to use English more frequently. The findings show that the teacher practiced code-switching not only because she is demanded to speak English. Besides due to the demand to facilitate students to learn English effectively, the habit of using English also tends to be the reason behind the practice of codeswitching. The habit of using English frequently forms a particular language processing in the teacher's brain, triggering the teacher to practice code-switching.

Based on the findings, the recommendations given are (1) further research on code-switching in various contexts be conducted, (2) further research on code-switching practiced by speakers with different habit of using English be conducted, and (3) teachers contemplate the necessity of using code-switching in their classroom.

\section{REFERENCES}

Alwasilah, A. C. (2015). Pokoknya Studi Kasus: Pendekatan Kualitatif. Bandung: Kiblat.

Bailey, C. S. (2007). A Guide to Qualitative Field Research 2nd Edition. Thousand Oaks: Pine Forge Press.

Barnes, J. D. (2006). Early Tringualism: A Focus on Questions. Toronto: Multilingual Matters LTD.

Bot, K. d., Lowie, W., \& Verspoor, M. (2005). Secong Language Acquisition: an advanced resource book. London: Routledge Taylor \& Francis Group.

Brown, H. D. (2000). Teaching by Principles: An Interactive Approach to Language Pedagogy. New York: Longman.

Cenoz, J. (2003). The Influence of Age on the Acquisition of English: General Proficiency, Attitudes and Code Mixing. In M. d. Mayo, \& M. L. Lecumberri, Age and the Acquisition of English as a Foreign Language (pp. 7793). Sydney: Multilingual Matters LTD.

Crystal, D. (2003). English as a Global Language (second ed.). New York: Cambridge University Press.

Ewert, A. (2010). An Educational Language Community: External and Internal Language Use by Multilingual Students. In J. Arabski, \& A. Wojtaszek, Neurolinguistic and Psycholinguistic Perspectives on SLA (pp. 159-174). Toronto: Multilingual Matters.

Fraenkel, J. R., Wallen, N. E., \& Hyun, H. H. (2012). How to Design and Evaluate Research in Education (eight ed.). New York: McGraw Hill. 
Gass, S. M., \& Selinker, L. (2008). Second Language Acquistion (third ed.). London: Routledge.

Harmer, J. (2007). The Practice of English Language Teaching (4th ed.). New York: Pearson Longman.

Holmes, J. (2001). An Introduction to Sociolinguistics (second ed.). Edinburgh: Pearson Education Limited.

Jenkins, J. (2009). World Englishes: A Resource Book for Student (second ed.). London: Routledge.

Judd, E. L. (1999). Some Issues in the Teaching of Pragmatic Competence. In E. Hinkel (Ed.), Culture in Second Language Teaching and Learning (pp. 152-166). Cambridge: Cambridge University Press.

Levin, B. (2003). Case Studies of Teacher Development: An In-Depth Look at How Thinking About Pedagogy Develops Over Time. London: Lawrence Erlbaum Associates Publishers.

Malik, R. S., \& Hamied, F. A. (2014). Research Methods: A Guide for First Time Researchers. Bandung: UPI Press.

McGrath, I. (2002). Materials Evaluation and Design for Language Teaching. Edinburgh: Edinburgh University Press.

McKay, S. L. (2003). EIL Curriculum Development. RELC Journal, 34(1), 31-47 [online: http:/ / rel.sagepub.com/content/34/

1/31 accessed 27 November 2013].

Nunan, D. (1992). Research Method in

Language Learning. Cambridge:

Cambridge University Press.

Peng, J., \& Zhang, L. (2009). An Eye of Target Language Use in Elementary English Classrooms in China. In M. Nikolov, Early Learning of Modern Languages: Process and Outcomes (pp. 212-228). Bristol: Multilingual Matters.

Qing, X. (2010). To Switch or Not to Switch: Examine the Code-Switching Practices of Teachers of Non-English Majors. Canadian Social Science, 6(4), 109-113.

Saito, A. (2012). Is English Our Lingua Franca or the Native Speaker's Property? The Native Speaker Orientation among Middle School Students in Japan. Journal of Language Teaching and Research, 3(6), 1071-1081.

Saville-Troike, M. (2006). Introducing Second Language Acquisition. Cambridge: Cambridge University Press.

\section{ACKNOWLEDGEMENTS}

I would like to sincerely extend our greatest gratitude to Jurnal Pendidikan Bahasa dan Sastra for publishing this article. Our highest appreciation also goes to those who have helped the whole process of writing and publishing this article. 